\title{
日本における石灰岩溶食率の経年変化とその地域性
}

\author{
漆原和子 ${ }^{1}$ 鹿島愛彦 ${ }^{2}$ 榎本浩 之 ${ }^{3}$ \\ 庫 本 正 $^{4}$ フランツ ディーター・ミオトケ ${ }^{5}$ \\ 仲程 正 $^{6}$ 比嘉 正 弘 $^{7}$
}

\section{Secular Change and Regional Differences of Limestone \\ Solution Rates in Japan}

Kazuko URUSHIBARA-YOSHINO ${ }^{1}$, Naruhiko KASHIMA ${ }^{2}$, Hiroyuki ENOMOTO ${ }^{3}$, Tadashi KURAMOTO ${ }^{4}$, Franz-Dieter MIOTKE ${ }^{5}$, Tadashi NAKAHODO ${ }^{6}$ and Masahiro HIGA ${ }^{7}$

\begin{abstract}
Observations of the solution rate of limestone tablets from 1993 to 1997 have been utilized to clarify the degree of karstification from northern to southern Japan.

Limestone tablets were placed at seven observation points stretching from northern to southern Japan: Toma, Abukuma, Chichibu, Akiyoshidai, Shikoku Onogahara, Ryugado, and Minamidaito. Three groups of four limestone tablets from Slovenia, Guilin (China), Chichibu, and the fourth tablet from limestone indigenous to the obsevation point, were arranged on three levels at each observation point: $1.5 \mathrm{~m}$ above the ground, the $\mathrm{A}_{3}$ horizon, and the $\mathrm{B}_{2}$ horizon. Measurements were taken of the solution rates of the tablets at each observation point from 1993 to 1997. Thornthwaite's method was used for calculating water balance to ascertain the relation between solution rate and water balance factors. The solution rates of limestone tablets placed $1.5 \mathrm{~m}$ above the ground show a high correlation coefficient between (water surplus (WS) minus water deficit (WD)). On the other hand, limestone tablets planted in the soil had a solution rate from two to three times higher than those suspended in the air. The solution rates of limestone tablets located in the $\mathrm{A}_{3}$ and $\mathrm{B}_{2}$ horizons exhibited the highest annual precipitation correlation coefficient. The high $\mathrm{CO}_{2}$
\end{abstract}

\footnotetext{
${ }^{1}$ 駒沢大学文学部自然科学教室

2 愛媛大学農学部森林資源学・森林環境制御研究室

3 北見工業大学工学部土木開発工学教室

4 秋吉台科学博物館

5 ハノーファー大学地理学教室

6 沖縄気象台通信課

7 南大東島地方気象台技術課

${ }^{1}$ Natural Science Faculty, Faculty of Letters, Komazawa University

2 Department of Forest Resources, Faculty of Agriculture, Ehime University

${ }^{3}$ Department of Civil Engineering, Kitami Institute of Technology

${ }^{4}$ Akiyoshidai Museum of Natural History

${ }^{5}$ Department of Geography, Hannover University

${ }^{6}$ Telecommunications Division, Okinawa Meteorological Observatory

${ }^{7}$ Technology Division, Minamidaitojima Local Meteorological Observatory
} 
values under warm, humid conditions may account for the higher solution rates of the tablets planted in the soil.

The solution rate tendency curve achieved its greatest range during the five years in direct proportion to the WS-WD ratio in 1993, when a cool, humid summer prevailed throughout most of Japan. The solution rate tendency curve marked its smallest range during the five years in proportion to the WS-WD ratio at all locations for limestone tablets suspended in air in 1994, under conditions of an extremely hot and dry summer, such as occurs only once in a hundred years. In general, however, the solution rates of the limestone tablets were high when the WS-WD ratio ranged between 1,000 to $1,600 \mathrm{~mm}$. Within this range, the solution rates at each observation point decreased slightly as the WS-WD ratio decreased.

Key words : karstification, limestone, solution rate, $\mathrm{CO}_{2}$ contents, water surplus, water deficit キーワード: カルスト化過程, 石灰岩, 溶食率, $\mathrm{CO}_{2}$ 濃度, 水過㮃量, 水不足量

\section{I. はじめに}

\section{1）研究目的}

日本における炭酸塩岩の地域は全国面積の 0.44 \%（漆原, 1996）に相当し，その占める面積はき わめて狭小である。しかし，世界的に地表面の炭 酸塩岩の面積は世界の陸地面積の約 $12 \%$ と推定 されている(Yuan, 1991)。近年, 炭酸塩岩が固 定している二酸化炭素量が全地球の二酸化炭素量 の大きな比率を占めることが注目されている。地 球温暖化に伴う溶解促進などによって, 炭酸塩岩 に固定されている二酸化炭素の挙動を予測するこ とに関心が払われつつある（Yuan，1997）。

溶食作用によって生じた多様なカルスト地形が 世界に分布するにもかかわらず，世界のカルスト 化過程の地域差がいかなる要素に強く規定されて いるのか明確にされていない。本論文ではモンスー ン気候下での日本のカルスト化過程の地域差と経 年変化を明確にすることを目的とした。

\section{2) 石灰岩溶食量の研究}

石灰岩の溶食に関してはカルスト研究者によっ て多大の関心が払われてきたが,ここでは，これ までの直接溶食量を測定しょうという試みの概略 を示す。

石灰岩片を用いて溶食量を計測する方法は Trudgill (1975), Jennings（1977）などの報告
がある。本論文では少なくとも岩質を均質に保つ ために,「カルスト」の語源の地であるスロベニ ア, クラス地方の石灰岩片試料を国際洞窟学連合 (ISU), 削剥委員会で配布したものを用いた。そ の測定方法と，すでに一部得られた測定例は Gams（1985）が報告している。その後中国でも 桂林七星岩の石灰岩片を用いて, その測定を始め ている。漆原（1991）はクラス地方の石灰岩片を 用い, 全国 8 地点の溶食量を計測した。また空中 での石灰岩の溶食の度合いを考える場合に，酸性 雨の影響を無視することはできない。吉村・中村 （1991）は秋吉台の酸性雨の影響による溶食量の 増加を約 $1 \%$ と見積もっている。

近年の酸性雨が土壤, 植生に及ぼす影響につい ては, 文部省の重点領域研究「酸性雨」班がとり あつかった。特に土䁃に対する影響は, 大羽 (1990), 岡崎（1990）等による成果が発表されて いる。また, 環境庁酸性雨土壤植生影響研究会 （1990）は, 酸性雨の土垬への環境予察図を発表 した。空中ばかりでなく, 土壌にもその影響が及 ぶことを指摘し, 同質の酸性雨が降っても土壤特 性に応じて緩衝能が違うので，その影響のあらわ れ方にも差があることを指摘している。今回の石 死岩片設置土壤はこの論文の暗赤色土, 褐色森林 土, レンジナ, クロボク土に相当するが, これら はいずれも酸性雨に対する耐性評価は高い。しか 
し, 土㙵中での石灰岩片の溶食量を測定する場合 には, 将来当然酸性雨の影響を考慮しなければな らない。

土壤中での石灰岩片の溶食量の差は, 多くの要 素が関与していると思われる。なかでも溶解の反 応に必要な水が保有されていること, すなわち, 湿った状態に長時間おかれていること，しかも溶 解を促進する温度範囲であること, 二酸化炭素の 濃度（分圧）が高い状態にあることが溶解を促進 させる重要な要因になるであろう。他に土壤の酸 度, 有機物含量, 有機物の性質, 植物の根の影響, 土壤構造，その他の土壤特性など，多くの要因が 考えられよう。土壤中の石灰岩の溶食に関しては Trudgill（1976）が, また二酸化炭素の測定とそ の役割については Miotke（1974）の研究がある。 日本でも土㙵中の二酸化炭素の測定は目崎 （1984）が秋吉，平尾台，沖縄で測定し，吉村 （1985）は秋吉台の草地と林地で測定した。いず れの結果も二酸化炭素濃度が地温とともに上昇し ていることを示している。また，上記の目崎は， 二酸化炭素と温度の関係から気候帯（気温と流出 量）の違いがカルスト地形形成に主要な役割を果 たすと推定している。

\section{II. 研究方法と試料}

\section{1) 試料}

石灰岩片は，スタンダードとしてスロベニア， クラス地方のリピツァ (Lipica) における中生代 白亜紀石灰岩を用いて直径 $4 \mathrm{~cm}$ 厚さ $4 \mathrm{~mm}$ に作 成し，これを使用した。この石灰岩片は，国際洞 窟学連合 (ISU) のカルスト削剥委員会で全世界 に配布したものと同じ試料である。この他にス夕 ンダードとして中国桂林の七星岩（古生代デボン 紀石灰岩）（Yuan Daoxian 氏による提供）と， 秩父武甲山の石灰岩（中生代三畳紀）の石灰岩片 も加えた。今回使用した石灰岩片はいずれも約 $12.5 \mathrm{~g} \sim 13.5 \mathrm{~g}$ と試料の重量にばらつきがあるた め, 溶食量を減少重量の実測值で比較するのには 問題がある。従って，ここでは一つの試料が設置 前と設置後で減少した量を溶食量とみなして，こ の量が設置前の重量に対して占める割合を百分率
で表わし，溶食率として表現した。この溶食率は 365 日換算をして, 各地点の比較および各試料間 の比較をおこなった。設置前にはシリカゲルを入 れたデシケーターの中で約 10 日間十分乾燥させ て, 安定した重量を得た後, 現地へ設置した。回 収後も設置前と同様の条件で十分乾燥させて, 安 定した後の重量を計測し, 減量を 365 日分に換算 した。

スタンダードとした上記の 3 種の石灰岩片は 7 観測地点の空中 $1.5 \mathrm{~m}$, 地中 $\mathrm{A}_{3}$ 層位と地中 $\mathrm{B}_{2}$ 層 位の位置に設置した。その他に観測地点それぞれ の場所の石灰岩を用いて同一規格の石灰岩片を作 成し，それぞれの観測地点の上記の三つの位置に 設置した。すなわち同一地点の同一位置には石灰 岩片 4 種 4 枚 1 組で設置した。

\section{2) 研究方法}

\section{1. 二酸化炭素濃度の測定法}

全国 7 地点の $\mathrm{CO}_{2}$ 濃度はガステック法を用いて 測定した。阿武隈は分光計, ドラガー法でも同時 に計測をし， $\mathrm{CO}_{2}$ 濃度がガステック法と相対的 に同一に変化することを確かめた（漆原・Miotke, 1998)。

2. 期間と設置条件

1993 年から 1997 年までの間に全国 7 地点（当 麻, 阿武隈, 秩父 (武甲山), 秋吉台, 四国大野 ヶ原, 龍河洞, 南大東) の石灰岩地域で観測した (表 1, 図 1)。地上の $1.5 \mathrm{~m}$ の設置点は, $1.5 \mathrm{~m}$ ポールの上端に水平に石灰岩片を設置し, 樹木の 影響の少ない開けた場所を選び，地表は背の低い 草におおわれているか, 丈の低い $1 \mathrm{~m}$ 以下の灌木 があるところを選んだ。できるだけ平坦な地形を 選び，地中の $\mathrm{A}_{3}$ 層位と $\mathrm{B}_{2}$ 層位に，土壌構造を乱 さぬように石灰岩片を埋め込んだ。秩父（武甲山） の空中 $1.5 \mathrm{~m}$ の設置例を写真で示した（写真 1$)$ 。

\section{III. 調査地域の概略}

\section{1）当麻}

観測地点当麻として表記した地点は, 旭川の東 に位置する当麻町営, 当麻鍾乳洞の入口である。 地点の位置は北緯 $43^{\circ} 49^{\prime} 30^{\prime \prime}$, 東経 $142^{\circ} 36^{\prime} 50^{\prime \prime}$ で ある。標高は約 $220 \mathrm{~m}$ で, 主としてシラカバを中 
表 1 石灰岩片設置点の環境.

Table 1 Environment of observation points.

\begin{tabular}{|c|c|c|c|c|c|c|c|}
\hline \multirow[t]{2}{*}{ 設置点 } & \multirow[t]{2}{*}{ 緯度, 経度 } & \multirow[t]{2}{*}{ 海抜高度 (m) } & \multicolumn{2}{|c|}{$\begin{array}{l}\text { 石灰岩片設置 } \\
\text { 土壤層位の深さ }\end{array}$} & \multicolumn{2}{|c|}{$\begin{array}{c}\text { 石灰岩片設置時の } \\
\text { 土壤 } \mathrm{pH}\end{array}$} & \multirow{2}{*}{$\begin{array}{c}\text { 炭酸塩岩の地質 } \\
\text { 年代と植生 }\end{array}$} \\
\hline & & & 土壤層位 & $(\mathrm{cm})$ & $\left(\mathrm{H}_{2} \mathrm{O}\right)$ & $(\mathrm{KCl})$ & \\
\hline \multirow{2}{*}{ 当 麻 } & \multirow{2}{*}{$\begin{array}{r}43^{\circ} 49^{\prime} 30^{\prime \prime} \mathrm{N} \\
142^{\circ} 36^{\prime} 50^{\prime \prime} \mathrm{E}\end{array}$} & \multirow{2}{*}{$220 \mathrm{~m}$} & $\mathrm{~A}_{3}$ & -20 & 5.70 & 4.90 & \multirow{2}{*}{$\begin{array}{l}\text { 二畳紀-三畳紀石灰岩 } \\
\text { 針葉樹と落葉樹の混交林 }\end{array}$} \\
\hline & & & $\mathrm{B}_{2}$ & -50 & 5.59 & 4.45 & \\
\hline \multirow{2}{*}{ 阿武隈 } & \multirow{2}{*}{$\begin{array}{r}37^{\circ} 20^{\prime} 30^{\prime \prime} \mathrm{N} \\
140^{\circ} 40^{\prime} 37^{\prime \prime} \mathrm{E}\end{array}$} & \multirow{2}{*}{$640 \mathrm{~m}$} & $\mathrm{~A}_{3}$ & -40 & 5.25 & 4.56 & \multirow{2}{*}{$\begin{array}{l}\text { 中生代の変成作用による } \\
\text { 大理石化を受けた石灰岩 } \\
\text { 落葉樹林と草地 }\end{array}$} \\
\hline & & & $\mathrm{B}_{2}$ & -60 & 5.40 & 4.35 & \\
\hline \multirow{2}{*}{ 秩 父 } & \multirow{2}{*}{$\begin{array}{r}35^{\circ} 57^{\prime} 15^{\prime \prime} \mathrm{N} \\
139^{\circ} 05^{\prime} 15^{\prime \prime} \mathrm{E}\end{array}$} & \multirow{2}{*}{$960 \mathrm{~m}$} & $\mathrm{~A}_{3}$ & -20 & 6.55 & 5.60 & \multirow{2}{*}{$\begin{array}{l}\text { 三疊紀石疢岩 } \\
\text { 落葉樹林と草地 }\end{array}$} \\
\hline & & & $\mathrm{B}_{2}$ & -45 & 6.43 & 5.31 & \\
\hline \multirow{2}{*}{ 秋吉台 } & \multirow{2}{*}{$\begin{array}{r}34^{\circ} 13^{\prime} 51^{\prime \prime} \mathrm{N} \\
131^{\circ} 18^{\prime} 34^{\prime \prime} \mathrm{E}\end{array}$} & \multirow{2}{*}{$240 \mathrm{~m}$} & $\mathrm{~A}_{3}$ & -20 & 5.38 & 4.21 & \multirow{2}{*}{$\begin{array}{l}\text { 石炭紀と二畳紀の石灰岩 } \\
\text { 常緑広葉樹と落葉樹の混 } \\
\text { 交林と草地 }\end{array}$} \\
\hline & & & $\mathrm{B}_{2}$ & -50 & 5.23 & 3.99 & \\
\hline \multirow{2}{*}{$\begin{array}{l}\text { 四国 } \\
\text { 大野ヶ原 }\end{array}$} & \multirow{2}{*}{$\begin{array}{r}33^{\circ} 28^{\prime} 24^{\prime \prime} \mathrm{N} \\
132^{\circ} 52^{\prime} 51^{\prime \prime} \mathrm{E}\end{array}$} & \multirow{2}{*}{$1,200 \mathrm{~m}$} & $\mathrm{~A}_{3}$ & -28 & 5.72 & 4.78 & \multirow{2}{*}{$\begin{array}{l}\text { 二畳紀石灰岩 } \\
\text { 落葉樹林と草地 }\end{array}$} \\
\hline & & & $\mathrm{B}_{2}$ & -60 & 5.13 & 4.10 & \\
\hline \multirow{2}{*}{ 龍河洞 } & \multirow{2}{*}{$\begin{array}{r}33^{\circ} 35^{\prime} 54^{\prime \prime} \mathrm{N} \\
133^{\circ} 44^{\prime} 53^{\prime \prime} \mathrm{E}\end{array}$} & \multirow{2}{*}{$280 \mathrm{~m}$} & $\mathrm{~A}_{3}$ & -20 & 6.05 & 5.06 & \multirow{2}{*}{$\begin{array}{l}\text { 三畳紀石灰岩 } \\
\text { 常緑広葉樹と草地 }\end{array}$} \\
\hline & & & $\mathrm{B}_{2}$ & -45 & 6.88 & 6.33 & \\
\hline \multirow{2}{*}{ 南大東 } & \multirow{2}{*}{$\begin{array}{r}25^{\circ} 49^{\prime} 42^{\prime \prime} \mathrm{N} \\
131^{\circ} 14^{\prime} 01^{\prime \prime} \mathrm{E}\end{array}$} & \multirow{2}{*}{$14 \mathrm{~m}$} & $\mathrm{~A}_{3}$ & -25 & 7.46 & 6.62 & \multirow{2}{*}{$\begin{array}{l}\text { 第四紀更新世石灰岩 } \\
\text { 常緑広葉樹と草地 }\end{array}$} \\
\hline & & & $\mathrm{B}_{2}$ & -45 & 7.32 & 6.65 & \\
\hline
\end{tabular}

心とする落葉樹と, 針葉樹の混合林で, 下ばえは チシマザサである。この林のゆるやかな斜面の土 壤中に石灰岩片を埋めた。北海道の石灰岩は, 古 生層および中生層中に層状ないしレンズ状に分布 するものと, 日高層群上部から空知層群にかけて の石灰岩層とに二分される（石灰石鉱業協会, 1983)。当麻周辺には白亚紀メランジ（当麻コン プレックスと命名されている）が分布し，中〜後 期二畳紀・後期三畳紀・ジュラ紀の石灰岩体を含 む。使用した当麻の石灰岩は二畳紀後期のもので ある。当麻には鍾乳洞が形成されているが, 地表 のカルスト地形は発達していない。

\section{2) 阿武隈}

調査地域は福島県滝根町, 常葉町, 大越町の境 界部に相当する仙台平である。石灰石鉱業協会 （1983）は釡山, 仙台平, 駒ヶ鼻付近の石灰岩は 古生層であると述べている。滝根町史編さん委員 会（1990）では中生代白亚紀の花崗岩類によって
時代未詳の滝根層群が接触変成をうけているので, 仙台平，中平付近の石灰岩はそれより古いという 立場をとっている。この石灰岩は再結晶し, 径数 $\mathrm{mm}$ の方解石からなる結晶質石灰岩（大理石）で ある。仙台平は約北緯 $37^{\circ} 21^{\prime}$ ，東経 $140^{\circ} 40^{\prime}$ に 位置し, その北に中平, 駒ヶ鼻と台地が続く。最 高の海抜高度は $850 \mathrm{~m}$ を超える。台地上はこの結 晶質石灰岩を溶食した残渣からなる土壤が重埴土 をなしている。しかし, 時代未詳の火山灰が混入 しており, 火山灰混入の度合いの強い表層は局地 的に有機物含量も高く, 土壤型はクロボク土であ る。しかし, 結晶質石灰岩の台地では B 層位は粘 土含量が高く, 土壤母材に溶食残渣が多く混じる 土壤と考えられるが, 土壤型は局地的に変化に富 む。地表では隣接する他の岩石との境界にポノー ル,ドリーネが発達し, 台地の地下には洞窟系が 形成されている。しかし，台地上にはドリーネは あまりよく発達していない。 


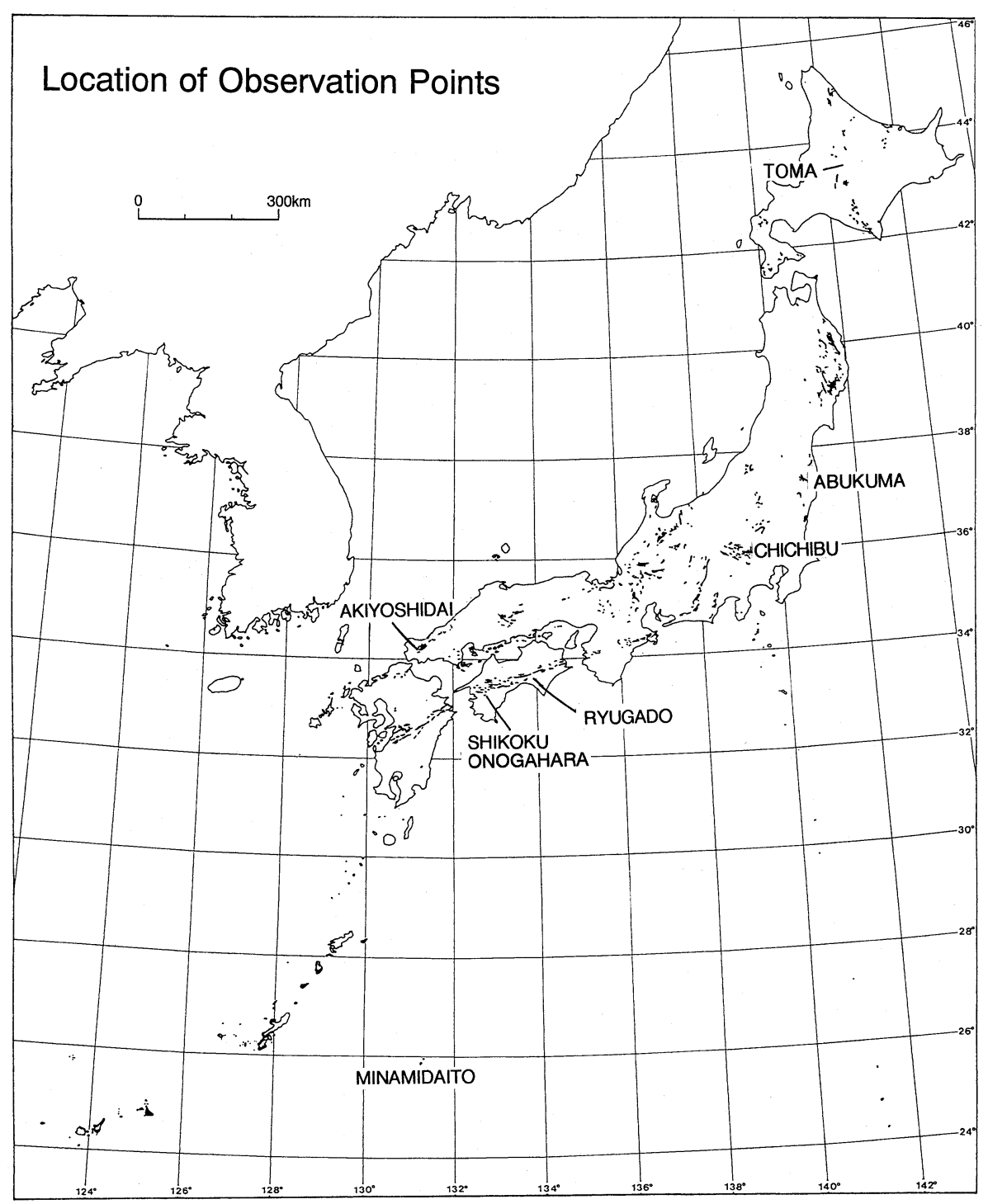

図 1 日本の石灰岩の分布と石灰岩片溶食測定地点.

Fig. 1 Limestone areas and locations of observation points in Japan.

\section{3）秩父（武甲山）}

観測地点は秩父武甲山の秩父小野田株式会社三 輪鉱業所の鉱区標高 $960 \mathrm{~m}$ である。採石場ベンチ 付近の自然林の中の草地を選んだ。地点は北緯 $35^{\circ} 57^{\prime} 15^{\prime \prime}$ ，東経 $139^{\circ} 5^{\prime} 15^{\prime \prime}$ に位置する。武甲山 の石灰岩は秩父中・古生層（武甲山総合調査会, 1987）と記載されている。ここでは漆原（1996）
に従って橋立層群の中の武甲山石灰岩の時代は中 生代三畳紀とした。武甲山はブナを主体とする落 葉樹林からなる。採石場であるため, カルスト地 形の原形は不明であるが, 採石場の断面にはドリー ネの跡が残る。

\section{4) 秋吉台}

秋吉台は東西約 $16 \mathrm{~km}$, 南北 $7.5 \mathrm{~km}$ の石灰岩 


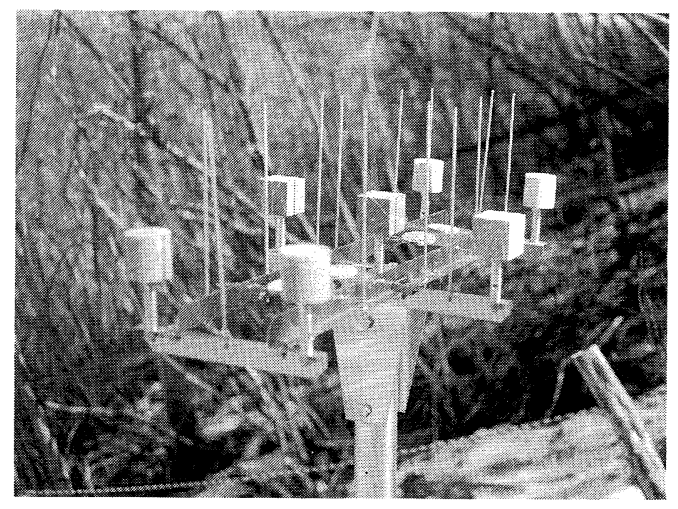

写真 1 空中の石死岩片設置例 (秩父, 1993 年).

Photo 1 Example of observation point (Chichibu, 1993).

台地である。東の台と西の台に分けられるが，調 査地点は東の台にある秋吉台科学博物館の敷地で, 北緯 $34^{\circ} 13^{\prime} 51^{\prime \prime}$, 東経 $131^{\circ} 18^{\prime} 34^{\prime \prime}$, 標高 $240 \mathrm{~m}$ で ある。石灰岩片の設置点は国立公園内であり，林 地に接したイネ科の草地を選んだ。

秋吉台の地質構造については永年にわたる研究 がある。太田正道（1968）とOta，M.（1977）に よれば, 秋吉石灰岩層は古生代前期石炭紀から後 期二畳紀にかけてのサンゴ礁複合体からなり，二 畳紀末～前期三畳紀の秋吉造山運動により，まず 石灰岩が褶曲をうけ, その後北からの傾動運動で 逆転構造ができたとされている。一方，小澤ほか (1985), 平（1990）は，秋吉台の石灰岩を二畳紀 付加体の一部として説明している。Sano and Kanmera（1991）は，秋吉石灰岩層群のほとんど 全体が礁-海山複合体衝突時の崩壊による破壊を うけていると述べている。秋吉台の石灰岩片を作 成した石灰岩は前期二畳紀に相当する。秋吉台に はドリーネ, ウバーレがよく発達した数段に分け られる台地が広がる。一部ピナクル群があり，そ の表面にカレンがよく発達するカレンフェルトが 広がる。

\section{5）四国大野ヶ原}

四国カルストと一般によばれている高原の上の 石灰岩地域は, 四国の代表的な 2 つ構造線, 中 央構造線と仏像構造線に挟まれた地域に位置する。 観測地点は北緯 $33^{\circ} 28^{\prime} 24^{\prime \prime}$, 東経 $132^{\circ} 52^{\prime} 51^{\prime \prime}$, 標
高 $1,200 \mathrm{~m}$ である。四国カルストは松山の約 45 $\mathrm{km}$ 南に位置し, 高原は $1,400 \mathrm{~m}$ から $1,500 \mathrm{~m}$ を 最高高度とし，ゆるやかな丘陵をなしている。四 国カルストとよばれる石灰岩地帯はこの高原上に 東西に長軸を持ち，幅約 $1 \mathrm{~km} \sim 2 \mathrm{~km}$ ，長さ約 25 $\mathrm{km}$ の範囲に分布する。四国カルストは古生代二 畳紀の石灰岩から構成される。観測地点の石灰岩 は弱く再結晶しているが，石灰岩として表示した。 地表にはカルスト地形がみられ, ドリーネ, ウバー レがよく発達し, 深さ $160 \mathrm{~m}$ の竪穴も発見されて いる。四国カルストの台地の一部にはカレンフェ ルトが分布する。戦後の入植者が主として牧畜を 営んだため, 四国カルストの地域は広く草地にお おわれ，一部落葉樹主体の灌木となるが，1,400 m 以上の高地にはブナ林があらわれる。

\section{6) 龍河洞}

龍河洞は四国を西南西から東北東に走る仏像構 造線北側付近に位置する。観測地点は北緯 $33^{\circ}$ $35^{\prime} 54^{\prime \prime}$, 東経 $133^{\circ} 44^{\prime} 53^{\prime \prime}$ で標高 $280 \mathrm{~m}$ である。 高知市から北東に約 $24 \mathrm{~km}$ の位置に相当する。白 亜系四万十川層群の上に上部三鳁系三宝山層群が 衝上した地域である。ここには三畳紀の石灰岩が オリストリスとして約 $500 \mathrm{~m}$ の長軸, $250 \mathrm{~m}$ 幅で 塊状に分布する。観測地点の石灰岩片はこの石灰 岩から作成した。観測地点から三宝山に連なる尾 根の背後には吸い込み穴があり, 龍河洞の水系に 連なる。松とコナラ属と照葉樹を主とする林地の 間の狭小な草地を観測地点として選んだ。林地内 にはピナクルが地表に露出し, その表面にはカレ ンがよく発達している。

\section{7）南大東島}

南北大東島は約 100 万年前に海溝周縁隆起帯に 位置したため，それまでの沈降しつつ環礁を形成 していった過程から，隆起環礁に転じたと推定さ れている (Konishi et al., 1978 ; 小西, 1980)。 サンゴ石灰岩はー4 $41 \mathrm{~m}$ までボーリングをした結 果，その地質時代は中新世初期にさかのぼること が知られている (Hanzawa, 1939)。小西 (1980) は南大東島の最新の裾礁（海抜 $11 \mathrm{~m}$ まで）は最 終間水期であるとした。そして，島の基底の大東 石灰岩は 133 万年以前であるとした。Koba et al. 
（1986）も海抜 $7 \mathrm{~m} \sim 12 \mathrm{~m}$ のサンゴの ESR 年代測 定をした結果, 最終間水期の值を得ている。太田 陽子（1990）による南大東島のサンゴの年代測定 も海抜 $8 \mathrm{~m}$ で, ほぼ $125,000 \mathrm{yr}$ B.P. の年代測定 を得ている。そして，この島の隆起を 0.04 $\mathrm{mm} \sim 0.05 \mathrm{~mm} /$ 年と推定している。この研究で使 用した「南大東島の石死岩片」は基底の大東石灰 岩を用いて作成した。南大東島の大東石灰岩のド ロマイト化作用は地域的に選択的におこなわれて いることが報告されている（鹿島，1975）。本論 文で, 南大東石灰岩片として用いた北港付近の試 料はきわめて微量のドロマイトを含むドロマイト 質石灰岩であるが, ここでは石灰岩と表現した。

南大東島は隆起環礁がその後のカルスト化作用 をうけ，島の周縁は環状に高く，2〜4列のライム ストーンウォールがある。これらの数列のライム ストーンウォールには, 植生に扔扔われていない 比高 $7 \mathrm{~m} \sim 8 \mathrm{~m}$ から $3 \mathrm{~m} \sim 4 \mathrm{~m}$ のピナクル群が形 成されている場所がある。しかし，比高の大きな ピナクルは 1980 年代末の農地の整理で多くは失 われてしまった。測定地点は標高 $14 \mathrm{~m}$ にある旧 南大東島地方気象台 (在所南), 北緯 $25^{\circ} 49^{\prime} 42^{\prime \prime}$, 東経 $131^{\circ} 14^{\prime} 01^{\prime \prime}$ の敷地内に設置した。石灰岩を 母材とする粘土含量 $80 \%$ を超える重埴土の赤色 土壤でおおわれている。山中式硬度計による土塞 の硬度は $\mathrm{A}_{3}$ 層位で $10.01 \mathrm{~kg} / \mathrm{cm}^{2}$ であるが, $\mathrm{B}_{2}$ 層 位で $20.09 \mathrm{~kg} / \mathrm{cm}^{2}$ ときわめて堅い。

\section{IV. 調 查 結 果}

\section{1）気候と水収支}

1993 年〜1997 年の観測地点の日降水量と旬別 平均気温を用いた。さらに土壤中の水収支を考慮 した方法である Thornthwaite（1948）法に基づ いて月別の水不足量 (WD), 水過剩量 (WS), 可能蒸発散量 $(\mathrm{E})$ の算出をおこなった。

当麻は日降水量と旬別気温と水収支の算出には 測候所旭川の気象観測值を用いた。阿武隈は日降 水量と旬別気温と, 水収支の算出のためにアメダ スによる小野新町の気象観測值を用いた。秩父 （武甲山）の旬別気温は, 秩父測候所の值に高度 補正 (月平均気温から $3.8^{\circ} \mathrm{C}$ をイナスする) を
して用いた。日降水量は秩父小野田株式会社が三 輪鉱業所の鉱区内で観測している数值を高度補正 （×1.09）して用いた。以下補正した気温, 降水 量に基づいて表示する。秋吉台は秋吉台のアメダ スの気温と降水量の観測值を用いた。 $\mathrm{CO}_{2}$ の測定, 溶食量の測定は, 秋吉台科学博物館敷地内でおこ なった。四国大野ヶ原の降水量は四国電力株式会 社ロボット設置点「大野ヶ原」のデー夕を使用し た。旬別気温は久万のアメダス気象観測值に高度 補正 (月平均気温から $3.6{ }^{\circ} \mathrm{C}$ をイナスする) を した。龍河洞の気候值は最も近い後免のアメダス のデータを用いた。旬別気温は後免の気象観測值 に高度補正（月平均気温から $1.4^{\circ} \mathrm{C}$ をイナスす る）をして用いた。南大東島は南大東島地方気象 台の観測値を用いた。 $\mathrm{CO}_{2}$ の観測地点と, 溶食量 の測定地点は同一の場所である。

\section{2) 土壤中の二酸化炭素濃度}

全国 7 地点の 5 年間の土壤中の二酸化炭素の測 定値は吉野（1998）に載せたので, それを参照さ れたい。

\section{$<$ 当麻>}

当麻では, 1993 年〜1997 年まで土壤中の $\mathrm{A}_{3}$ 層 位と $\mathrm{B}_{2}$ 層位において季節ごとに年 4 回ガステッ ク法によって計測した。 $\mathrm{A}_{3}$ 層位はー $20 \mathrm{~cm}, \mathrm{~B}_{2}$ 層 位はー50 cm である。

$<$ 阿武郎 $>$

阿武隈では, 土壤中の $\mathrm{CO}_{2}$ 濃度の測定は 3 方法 によって試みた。特に定点観測を続けた地点では, ガステック, 分光計, ドラガー法の比較を試みた。 本論文では他の地点と同様ガステック法の測定值 を示した。 $\mathrm{CO}_{2}$ 濃度の測定は $\mathrm{A}_{3}$ 層位は $-40 \mathrm{~cm}$,

$\mathrm{B}_{2}$ 層位はー $60 \mathrm{~cm}$ で扔こなった。

$<$ 秩父 (武甲山) $>$

秩父は武甲山の北向き斜面に相当し，この地点 のみ観測地点は傾斜約 $12^{\circ}$ である。従って, 土壤 中の湿度は他の地点より常に乾燥ぎみである。ま た標高は $960 \mathrm{~m}$ であり, 緯度に対して地温は低い。 $\mathrm{A}_{3}$ 層位はー $20 \mathrm{~cm}, \mathrm{~B}_{2}$ 層位は $-45 \mathrm{~cm}$ で $\mathrm{CO}_{2}$ 濃 度をガステック法により測定した。1993 年〜1997 年の 4 季節の $\mathrm{CO}_{2}$ 濃度は常に 7 地点中ほぼ最低值 を示している。 

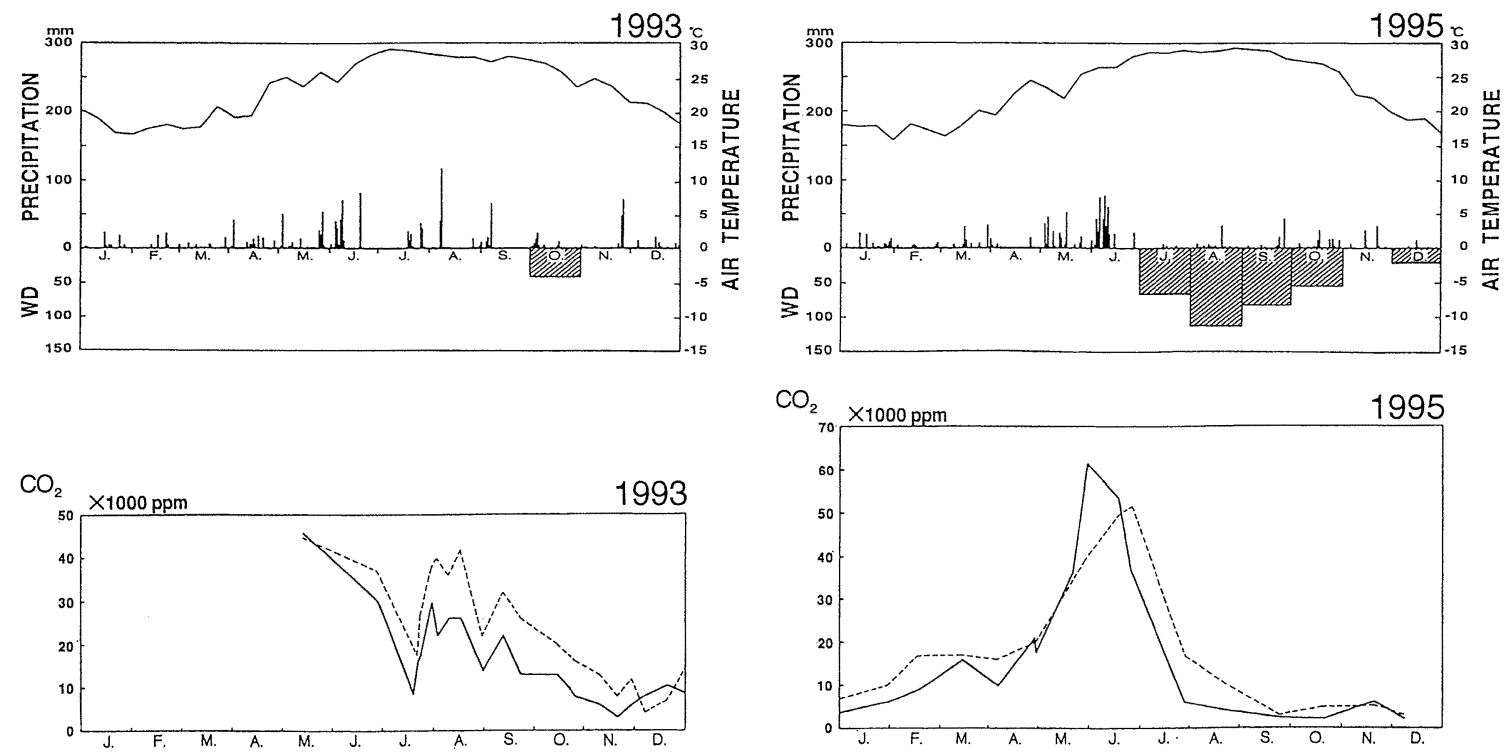

図 2 南大東島における 1993 年と 1995 年の $\mathrm{CO}_{2}$ 濃度と日降水量, 旬別気温と水不足量.

Fig. $2 \mathrm{CO}_{2}$ values and climatic conditions at Minamidaito Island in 1993 and 1995.

\section{$<$ 秋吉台>}

1993 年〜1997 年にガステック法による $\mathrm{CO}_{2}$ 濃 度の測定は原則として毎月おこなった。 $\mathrm{A}_{3}$ 層位 はー $20 \mathrm{~cm}, \mathrm{~B}_{2}$ 層位は $-50 \mathrm{~cm}$ で $\mathrm{CO}_{2}$ 濃度の測定 をおこなった。暖候季の $\mathrm{CO}_{2}$ 濃度を比較すると， 1994 年 8 月以降はきわめて高温でかつ乾燥であっ たことを反映して，5年間で最低の值を示す。

<四国大野ヶ原>

1993 年〜1997 年までガステック法により, $\mathrm{CO}_{2}$ 濃度の測定をおこなった。1994 年〜1997 年には, 同時に分光計による測定を加えて測定值の検討を した。 $\mathrm{A}_{3}$ 層位はー $28 \mathrm{~cm}, \mathrm{~B}_{2}$ 層位はー $60 \mathrm{~cm}$ で測 定をおこなった。ガステック法による測定は，寒 候季にきわめて低く，暖候季には $\mathrm{CO}_{2}$ 濃度が高 まることを示している。しかし， $\mathrm{B}_{2}$ 層位で 5,000 $\mathrm{ppm}$ を超えたのは 1993 年の 8 月である。1996, 1997 年の夏は $\mathrm{A}_{3}$ 層位で $5,000 \mathrm{ppm}$ を上回った。

<龍河洞>

1993 年〜1997 年にはガステック法で測定した。 1994 年〜1997 年には分光計による $\mathrm{CO}_{2}$ 濃度の測 定も加えておこなった。 $\mathrm{A}_{3}$ 層位は一 $20 \mathrm{~cm}, \mathrm{~B}_{2}$ 層 位はー4 $5 \mathrm{~cm}$ で測定した。1993 年は湿潤年であり,
5月～11月まで高い $\mathrm{CO}_{2}$ 濃度を示している。1994， 1995, 1996 年はいずれも乾燥高温な年であり, 8 月の $\mathrm{CO}_{2}$ 濃度が高い。特に $\mathrm{A}_{3}$ 層位では 15,000 ppm となっている。

<南大東 $>$

南大東に扔けるガステック法による $\mathrm{CO}_{2}$ 濃度 の測定は $\mathrm{A}_{3}$ 層位 $(-25 \mathrm{~cm})$ と $\mathrm{B}_{2}$ 層位 $(-45$ $\mathrm{cm})$ においておこなった。

1993 年は特に $\mathrm{CO}_{2}$ 濃度に対する雨の効果をみ るために一雨 $20 \mathrm{~mm}$ を超えた雨が降った後と， 乾いた時期が続いた時には必ず測定した。漆原ほ か（1997）に述べたように，1993年は，少なくて も $20 \mathrm{~mm}$ を超える雨が降ると，3 日〜4 日後に必 ず $\mathrm{CO}_{2}$ 濃度は高くなっている。1993 年の最高濃 度は 40,000 ppm を超している。どの季節も $\mathrm{B}_{2}$ 層 位が常に $A_{3}$ 層位よりも高い。しかし 12 月には $\mathrm{A}_{3}$ 層位の方が $\mathrm{B}_{2}$ 層位を上回り，逆転がみられる。 年間を通じて温暖で雨が降る時期に高濃度である が, 冬季低温になると, その数值は $5,000 \mathrm{ppm}$ ま で低下する（図 2)。1994 年については前述論文 を参照されたい。

1995 年は乾湿の差がはっきりしている年であり， 


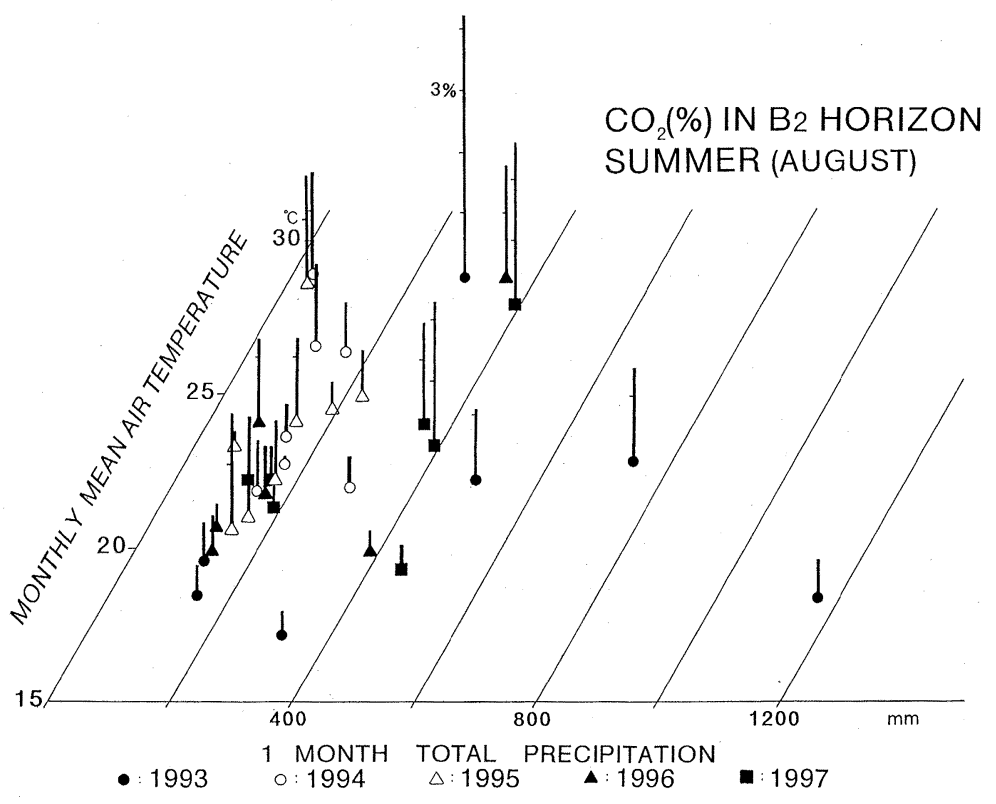

図 38 月の $\mathrm{B}_{2}$ 層位における土壤中の $\mathrm{CO}_{2}$ 濃度 (1993-1997 年).

$\mathrm{Y}$ 軸 : 計測月の平均気温, $\mathrm{X}$ 軸 : 計測日より 1 カ月前までの降水量

Fig. 3 Soil $\mathrm{CO}_{2}$ in the $\mathrm{B}_{2}$ horizon, monthly mean air temperature and one month precipitation prior to measurement, August 1993-1997.

5，6月には雨が多かったが，6月以降まとまった 十分な雨はなかった。従って $7,8,9,10$ 月と 12 月には水不足量 WD が生じ，その合算量も 337 $\mathrm{mm}$ と,これまでの 2 年間とは比較にならないほ ど大であった。 $5 ， 6$ 月には地温の上昇と多雨な状 況が一致したため $\mathrm{A}_{3}$ 層位では 3 年間の最高值 $60,000 \mathrm{ppm}$ を示した。しかし雨が降らないとす ぐに $\mathrm{CO}_{2}$ 濃度は低下する。一方 $\mathrm{A}_{3}$ 層位の約 1 カ 月遅れで $\mathrm{B}_{2}$ 層位の $\mathrm{CO}_{2}$ 濃度が上昇し, 7 月初め に最高の 50,000 ppm に達した。しかし，高い $\mathrm{CO}_{2}$ 濃度の時期は 5 月末〜 7 月初めで終わり, 年間を 通して, 3 年間のうち最も長い乾燥傾向がみられ, 8，9，10月に $\mathrm{A}_{3}$ 層位では $5,000 \mathrm{ppm} \sim 3,000 \mathrm{ppm}$ の低い值を示した。暖候季の $\mathrm{CO}_{2}$ 濃度は, 土畩 水分が十分湿って生物の活動が活発におこなわれ ている時に高まるといってよい。

全国の夏 (8月) と冬 (2月) の $\mathrm{CO}_{2}$ 濃度を図 3,4 に示した。これらの図に示される 5 年間の全 国の $\mathrm{CO}_{2}$ 濃度の観測結果から次のことがわかっ た。
（1） 1 年間の $\mathrm{CO}_{2}$ 濃度には季節変化があり, $\mathrm{A}_{3}$, $\mathrm{B}_{2}$ 層位ともに, 夏高く, 冬低い。

（2）一般に $\mathrm{B}_{2}$ 層位の方が $\mathrm{A}_{3}$ 層位よりも $\mathrm{CO}_{2}$ 濃度が高い。しかし, 雨量が $\mathrm{A}_{3}$ 層位のみを 湿らせる程度の時は $\mathrm{A}_{3}$ 層位の $\mathrm{CO}_{2}$ 濃度の方 が高い。

(3) $\mathrm{CO}_{2}$ 濃度の経年変化はきわめて大きく, 気 温の変化よりも大であり, 高温で高濃度の $\mathrm{CO}_{2}$ 濃度を示すはずの暖候季に雨が十分降ら ない場合には, $\mathrm{CO}_{2}$ 濃度は著しく低下する。

以上の (1) 〜 (3) の現象から, $\mathrm{B}_{2}$ 層位の $\mathrm{CO}_{2}$ が高濃度であることを持続できる理由を次のよう に考察した。有機物の分解で生産される $\mathrm{CO}_{2}$ や, 草の根の呼吸によって生産される $\mathrm{CO}_{2}$ は, 孔隙 率の小さい $\mathrm{B}_{2}$ 層位に混入し, そのまま保存, 蓄 積される。重埴土である $\mathrm{B}_{2}$ 層位の $\mathrm{CO}_{2}$ の放出は 少なく, 従って高濃度の $\mathrm{CO}_{2}$ を保存できる。 $\mathrm{A}_{3}$ 層位においては $\mathrm{CO}_{2}$ の生産量は大きいが, 孔隙 から空中に放出される量が大であり, $\mathrm{CO}_{2}$ 濃度は 結果的に低い值を示す。 


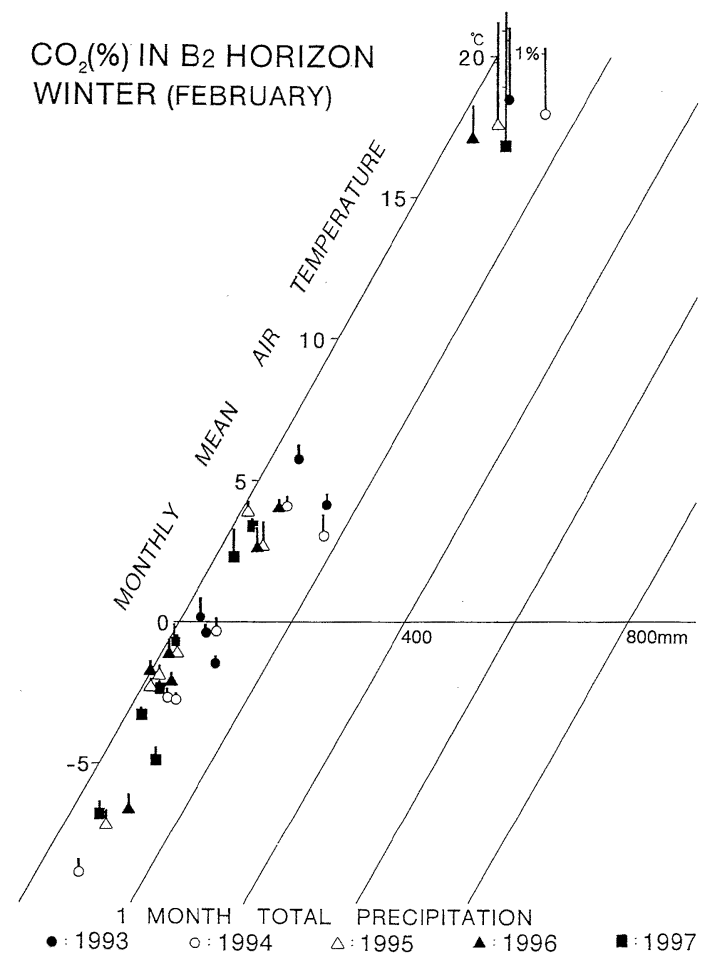

図42月の $\mathrm{B}_{2}$ 層位における土壤中の $\mathrm{CO}_{2}$ 濃度 (1993-1997 年).

$\mathrm{Y}$ 軸 : 計測月の平均気温, $\mathrm{X}$ 軸 : 計測日より 1 力月前までの降水量

Fig. 4 Soil $\mathrm{CO}_{2}$ in the $\mathrm{B}_{2}$ horizon, monthly mean air temperature and one month precipitation prior to measurement, February 1993-1997.

\section{3) 石灰岩片の溶食率}

7 地点の地上 $1.5 \mathrm{~m}$ と土壤中の $\mathrm{A}_{3}$ 層位と $\mathrm{B}_{2}$ 層 位に 4 種づつ設置をした石灰岩の溶食率は次のこ とを示している。

4 種の石灰岩片における 1 年間の石灰岩片の溶 食率を個々に比較すると, 桂林石灰岩片が最もよ く溶ける。湿潤年には 4 種の石灰岩片の平均值に 対して約 $10 \%$ １6％大きな溶食率を示す。しか し, 乾燥年には他種の石灰岩片よりもむしろ溶食 率が小さい。桂林石灰岩片は岩質的に湿潤な環境 に対して、よりよく溶解する要素を備えていると 考えられる。これは桂林石灰岩片の方解石の結晶 の大きさが他の岩石に比べて特に小さく, スロベ ニアの石灰岩片の約 $2 / 3 \sim 1 / 2$ で, 平均直径約 10 $\mu \mathrm{m}$ である。従って, 溶解反応のための鉱物の表 面積の合計が他の石灰岩より広くなるからと考え た。

全国 7 地点における 1993 年〜1997 年において 石灰岩片の溶食率は，4種の石灰岩片の平均値を 用いた。空中の石死岩片の溶食率は土壤中の $\mathrm{A}_{3}$ 層位の約 $1 / 3 \sim 1 / 2$ にすぎない。 $\mathrm{B}_{2}$ 層位は多少の 例外はあるが，一般的に $\mathrm{A}_{3}$ 層位よりも高い溶食 率を示している。これは，各地点の暖候季の $\mathrm{CO}_{2}$ 濃度が $\mathrm{B}_{2}$ 層位では $\mathrm{A}_{3}$ 層位より高いことに関わっ ていると考えられる。

1993 年〜1995 年の 3 年間の四国と龍河洞の溶 食の結果については, Kashima et al. (1996a, b), 鹿島ほか (1997), 漆原ほか（1998）, Urushibara-Yoshino et al. (1998) で述べてい る。以下は 5 年間の溶食率について述べる。

1. 1993 年〜1997 年の溶食率と気候要素

各地点の 1993 年から 1997 年までの 5 年間の空 中と地中の溶食率と気候要素, 水収支との間の相 関係数を求め, 相関マトリックスを表 2 に示した。 年降水量 $(\mathrm{P})$, 水過剩量 (WS), 水過剩量一水不 足量 (WD), 年降水量一可能蒸発散量 $(\mathrm{E})$ と, 溶食率の間ではすべて有意な正の相関を示す。

空中においては，溶食率とWS-WD との間で は $1 \%$ レベルで有意な正の相関を示し, $r=0.749$ である。次いで $\mathrm{P}-\mathrm{E}$ との間で $\mathrm{r}=0.745$ を示し, $\mathrm{WS}$ との間で $\mathrm{r}=0.745$ である。しかし, 年降水量 との相関係数は最も小さい。

$\mathrm{A} 3$ 層位に抒いては, 溶食率と年降水量との間 で $1 \%$ レベルで有意な正の相関を示し, $r=0.485$ である。次いでWS との間で $\mathrm{r}=0.426, \mathrm{WS}-\mathrm{WD}$ との間で $\mathrm{r}=0.409$ である。しかし， $\mathrm{P}-\mathrm{E}$ との間 の相関係数は最も小さい。

$\mathrm{B}_{2}$ 層位においても, 溶食率と年降水量との間 で $1 \%$ レベルで有意な正の相関を示し， $\mathrm{r}=0.562$ である。次いでWS との間で $\mathrm{r}=0.436, \mathrm{WS}-\mathrm{WD}$ との間で $\mathrm{r}=0.418$ である。しかし， $\mathrm{P}-\mathrm{E}$ との間 の相関係数は最も小さい。

3 年間と 5 年間の溶食率と気候要素, 水収支と の間の相関関係はいずれも正で，有意水準の高い 相関を有する要素は変わらない。すなわち, 空中 
表 2 石灰岩片溶食率と気候要素の相関マトリックス（1993-1997年).

Table 2 Correlation matrix of 5 years (1993-1997) between solution rates of limestone and climatic factors.

\begin{tabular}{c|c|c|c|c}
\hline & PREC. & WS & WS-WD & P-E \\
\hline $\begin{array}{c}\text { ABOVE THE } \\
\text { GROUND }\end{array}$ & $\mathrm{r}=0.695$ & $\mathrm{r}=0.744$ & $\mathrm{r}=0.749$ & $\mathrm{r}=0.745$ \\
\hline $\begin{array}{c}\mathrm{A}_{3} \\
\text { HORIZON }\end{array}$ & $\mathrm{r}=0.485$ & $\mathrm{r}=0.426$ & $\mathrm{r}=0.409$ & $\mathrm{r}=0.406$ \\
$\begin{array}{c}\mathrm{B}_{2} \\
\text { HORIZON }\end{array}$ & $\mathrm{r}=0.562$ & $\mathrm{r}=0.436$ & $\mathrm{r}=0.418$ & $\mathrm{r}=0.416$ \\
\hline
\end{tabular}

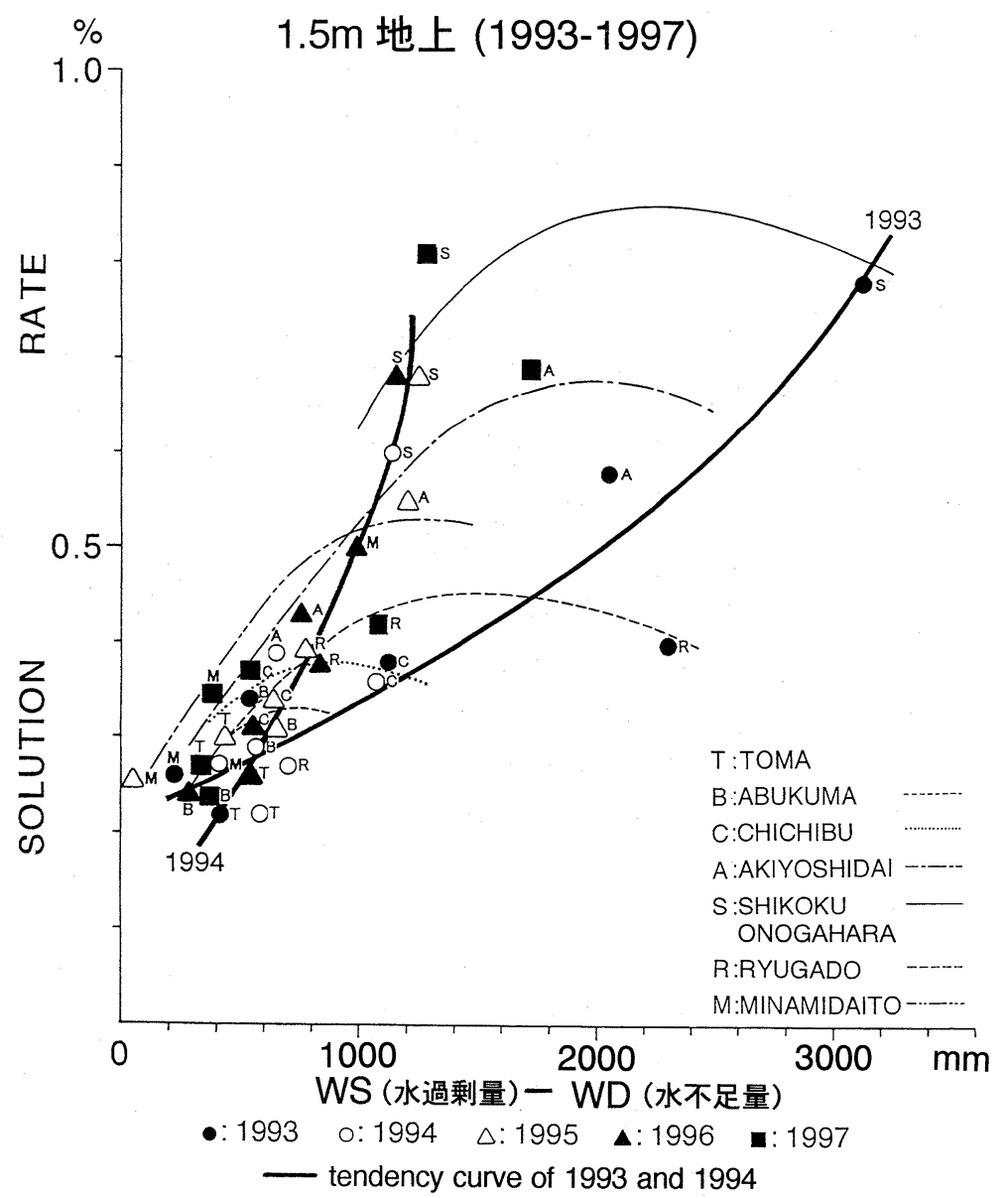

図 5 地上 $1.5 \mathrm{~m}$ の石灰岩片溶食率の傾向曲線（1993 年-1997 年). 1993 年 : 湿潤冷涼な夏, 1994 年 : 乾燥温暖な夏

Fig. 5 Tendency curves of solution rate at $1.5 \mathrm{~m}$ above the ground at each observation point.

1993: wet and cool summer, 1994 : dry and hot summer 
$1.5 \mathrm{~m}$ では石灰岩片の溶食率はWS-WD との間で 最も大きい相関係数を示す。溶食量は降水量と石 灰岩片が降雨に触れている時間の長さに支配され ていることを示していると考えられる。

$\mathrm{A}_{3}$ 層位と $\mathrm{B}_{2}$ 層位中の石灰岩片の溶食率は 3 年 間の場合も, 5 年間の場合も年降水量との間で有 意な正の相関をなし, 相関係数は最も大きい。こ のことから, 土壤中では年降水量のような長期間 の土壤中の水分量を示す要素の方が溶食率を決め ているといってよいようである。暖候季に雨が多 く, しかも目立った乾季がない日本のような気候 条件下では, 年降水量と並行して土䁃中の溶食量 は変化しているといえる。3 年間と 5 年間の結果 から, 溶食率を支配している共通要素は以上のよ うに明確になった。

2. 空中 $1.5 \mathrm{~m}$ の石灰岩片溶食率の経年変化 それぞれの地点の 1993 年から 1997 年までの溶 食率と（WS-WD）をプロットし, 各地点の 5 年 間の数值をみると, 7 地点で溶食率が高いのは四 国大野ヶ原, 秋吉台, 龍河洞の順である。各地点 5 年間の值は $\mathrm{B}$ : 阿武德, $\mathrm{C}:$ 秩父, $\mathrm{A}$ : 秋吉台, $\mathrm{S}$ : 四国大野ヶ原, $\mathrm{R}$ : 龍河洞, $\mathrm{M}$ : 南大東島の 線で示すように傾向線が引ける（図 5)。ただし， 当麻は数值幅がせまく, この図上で線を引くこと はできない。すなわち，WS-WDの值が大きくな れば単純に溶食率が高まるのではなく, 同一地点 で溶食率が高くなるための WS-WD の最適の数 值があり，それを超えると必ずしも溶食率が高ま るわけではないようである。

1993 年は 5 年間のうち最も湿潤な年のパターン としてあげられる。この年の 7 地点の中心を通る 傾向曲線は 5 年間のうち最も大きいWS-WD の数 值を示す。しかし, 溶食率では同一地点で 5 年間 の溶食率を比較する限り, 必ずしも最大の溶食率 を示す年ではない。1994 年は 100 年に一度といわ れる乾燥した高温な夏を経験した年であるが, 図 5 の 1 年間の 7 地点の溶食率と WS-WD の傾向曲 線は最小の数值を示す。この年は乾燥の度合いが 大であった秋吉と四国大野ヶ原, 龍河洞では 5 年 間で最小の溶食率を示した。

\section{V. まとめと今後の問題点}

\section{1）全国 7 地点における溶食率}

当麻, 阿武隈, 秩父 (武甲山), 秋吉台, 四国 大野ヶ原, 龍河洞, 南大東に至る 7 地点の石灰岩 片の溶食率から日本のカルスト化過程について, 次のことがわかった。

（1）各地点では空中 $1.5 \mathrm{~m}$ の石灰岩片の溶食率 は $\mathrm{A}_{3}$ 層位の $1 / 3 \sim 1 / 2$ である。また， $\mathrm{A}_{3}$ 層位と $\mathrm{B}_{3}$ 層位では $\mathrm{B}_{2}$ 層位がより高い溶食率を示す。こ のことは, 暖候季にどの地点でも $\mathrm{B}_{2}$ 層位で $\mathrm{CO}_{2}$ 濃度が高くなることを反映していると思われる。 $\mathrm{A}_{3}$ 層位は $\mathrm{CO}_{2}$ の生産の場であるにもかかわらず, 土壤構造上, 孔隙率も高く, 地上への $\mathrm{CO}_{2}$ ガス の発散もおこなわれていると考えた。一方， $\mathrm{B}_{2}$ 層位では孔隙率が低く，いったん供給された $\mathrm{CO}_{2}$ ガスを長く保有していると考えられる。

土畩中の溶食率は空中 $1.5 \mathrm{~m}$ の溶食率の $2 \sim 3$ 倍ある。このことは, 裸出カルストと, 被覆カル ストの溶食進行速度に大きな差があることを示し ている。5 年間の計測から現在の日本の気候下で の，土壤におおわれた石灰岩の溶食のスピードが 明確になった。

（2）当麻から南大東に至る空中と土壤中の溶食 率の差をみると, どの年も本州域では, より南ほ ど大きな溶食率を示す。すなわち四国大野ヶ原や 秋吉台は高い溶食率を示す。しかし, 南大東島は 暖候季に蒸発散が盛んであり，かつ乾燥する期間 があるので, 特に空中では, 降水と石灰岩との反 応時間が短くなる。従って溶食率は秋吉台や四国 大野ヶ原より小さい值を示す。本州域の中で四国, 中国地方は降水と温度が溶食スピードを高める範 用にあるため, 効果的にカルスト化が進み, ドリー ネ群やカレンフェルトがよく発達した地形が存在 すると考える。

（3） 1993 年から 1995 年の 3 年間では, 各年の 気候条件によって各地点とも空中と土塞中の石灰 岩片の溶食率に大きな年変動がある。1993 年は全 国的に湿潤で年降水量も大な年であり, 石灰岩片 の溶食率は 3 年間のうち最大を示す地点が多かっ た。一方 1994 年は夏季特に高温で乾燥した年で 
あり, 各地点の溶食率もこの気候条件を反映して 最小を示す地点が多かった。このことは年々の降 水量とその頻度が, 石灰岩片を溶解する化学反応 を促進し得たかどうかが重要であることを示して いる。

（4）石灰岩片の溶食率は気候值, 水収支の 5 年 間の相関マトリックスからみると, 空中 $1.5 \mathrm{~m}$ の 溶食率はWS-WD との間に正の有意水準 $1 \%$ の相 関関係が成立し, 相関係数は最も大きい。このこ とから, 降雨の量と時間が溶解の反応に関与し, 乾燥の時間や, その強度は溶解にとってマイナス 要素となっていることが判明した。このことは乾 季のある気候帯にあっては空中にそびえ立つピナ クルや, 塔カルスト等の溶食量は少なく, 年間を 通じて降雨時間や霧時間の長い気候帯では溶食量 は多くなることを明確に示している。

$\mathrm{A}_{3}$ 層位の溶食率と $\mathrm{B}_{2}$ 層位の溶食率は年降水量 と有意水準 $1 \%$ で正の相関がある。土壤中にあっ ては余剩の降水を土塞水分として保有している時 間が長く, 降雨の後, 2 日 3 日遅れで土壤中の $\mathrm{CO}_{2}$ 濃度が高まることからも, 持続した溶解反応 時間は, むしろ年降水量と相似であることを示し ている。土壤中の溶食率は少なくても温帯モンスー ン気候下では年降水量と相似であることが明確に なった。

\section{2) 今後の問題点}

空中 $1.5 \mathrm{~m}$ と土壤中において石灰岩が年単位で どれくらい溶解するのか, またどのような要素に 溶食率が規定されているのかを上記の通り明らか にすることができた。しかし，これまでの 5 カ年 間の溶食率の年変動が永年のパターンをすべて含 んでいるのかどうかの問題点が残る。さらに長期 の計測が必要であろう。また, 今後石灰岩層の地 下水系を通して排水された水がどの程度のカルシ ウムの溶解をし, どの程度のカルシウムの集積を 起こすのかを, 同じ生態系の中で確認していく必 要がある。また桂林石灰岩が最もよく溶けること で指摘したように, 粒度や組織による孔隙率や透 水率の差の考察も必要である。

\section{謝 辞}

5 年間の石灰岩片の溶食量測定には次の諸機関, 諸氏 の御協力をいただきました。心よりお礼申し上げます。 北海道当麻町役場商工観光課, 当麻鍾乳洞管理事務所, 福島県滝根町役場観光課, あぶくま洞管理事務所, 入水 鍾乳洞管理事務所, 秩父小野田株式会社三輪鉱業所, 秋 吉台科学博物館, 愛媛県大野ヶ原町武田 宽氏, 四国電 力株式会社建設部, 高知県龍河洞保存会, 南大東島地方 気象台台長㧍よび技術課, 沖縄気象台台長および技術課。 なお，スタンダードとして使用した石灰岩片は, スロベ ニア, リュブリヤナ大学 Ivan GAMS 教授, 中国桂林 岩溶研究所前所長猿 道先教授から提供いただいた。ま た, 日本の 7 地点の石灰岩は上記の諸機関から提供いた だいたことを記して感謝いたします。

南大東島に打ける二酸化炭素測定は, 著者のほかに元 南大東島地方気象台技官の佐々木正和氏, 新垣和夫氏,

喜納宏之氏も抗こなった。諸氏には正確な測定を続けて 下さったことを深く感謝いたします。

本研究は平成 7, 8, 9 年度文部省科学研究費基盤研究 （c）（2）課題番号 07680190 の補助をうけた。また，土 壤中の二酸化炭素の測定は平成 6 年度日本学術振興会外 国人招へい研究者招へい（短期）, ID No. S-94192に よる，F.-D. MIOTKE 教授の来日によってドラガー法 による測定ができた。

\section{文献}

武甲山総合調查会 (1987): 秩父武甲山総合調查報告書 上巻, 自然編. 武甲山総合調査会, $647 \mathrm{p}$.

Gams, I. (1985): International comparative measurement of surface solution by means of standard limestone tablets. Zbornik Ivana Rakovica, Razprave 4, Razrada Sazu, 26, 361386.

Hanzawa, S. (1939): Studies on the foraminiferal fauna found in the cores from the deep well in Kita-Daito-Zima (North Borodino Island). Proc. Imp. Acad. Japan, 14, 384-390.

Jennings, J.N. (1977): Limestone tablets experiments at Cooleman Plains, New South Wales, Australia and their implications. Abh. Karst und Höhlenkunde, A, 15.

環境庁酸性雨土䁃植生影響研究会 (1990): 酸性雨土壤 植生への影響, 付図酸性雨の土壤への影響予察図 (1/400 万). 公害対策研究センター, $198 \mathrm{p}$.

鹿島愛彦 (1975): 南大東島大東石灰岩, とくにそのド ロマイト化作用についての一考察. 愛媛大学紀要自然 科学 D シリーズ (地学), 7-4, 7-13.

Kashima, N. and Urushibara-Yoshino, K. and Research Group of Solutional Denudation 
Measurement of Limestone (1996a): Solutional denudation rate of limestone in Shikoku, Southwest Japan. Proc. 30th Int. Geol. Cong., 3, 434 .

Kashima, N., Urushibara-Yoshino, K. and Research Group of Solutional Erosion Measurement of Limestone (1996b): Karren development. Solutional erosion measurements by the limestone-tablet method in Shikoku Island, Southwest Japan. In Fonos, J-J. and Gines, A. eds. : Karren landforms. Universitat de les Illes Balears, Palma de Mallorca, 6573.

鹿島愛彦・漆原和子・榎本浩之・庫本 正・喜納宏之・ Miotke, F.D. (1997): 四国カルストにおける石灰 岩の溶食量測定. 愛媛の地学研究, 1, 62-64.

Koba, M., Tamura, M., Ikeya, M., Kaigara, T., Nakashima, H. and Kan, H. (1986): Quaternary shorelines and crustal movements on Minamidaito-jima, Northwestern Pacific. Proc. Intern. on Sea-level Changes, Chiba Ocean Press, 188-198.

小西健二 (1980): 隆起サンゴ礁からみた最終間水期以 降のアジア・フィリピン海プレート境界付近の地史一 同位体記録を中心に一。第四紀研究，18，241-250.

Konishi, K., Komura, K. and Motoya, Y. (1978): An early Wisconsin reef on the Daito Ridge, North Philippine Sea-Isotopic evidence-. Proc. Japan Acad., 54B, 516-521.

目崎茂和（1984)：日本の主要カルストの地形形成につ いて. 琉球大学法文学部紀要史学. 地理学編, $27 / 28$, 139-169.

Miotke, F.-D. (1974): Carbon dioxide and the soil atmosphere. Abh. Karst und Höhlenkunde, A, 9, 1-49.

岡崎正規 (1990): 土壤に対する酸性降下物の影響.「酸 性雨が陸域生態系におよぼす影響の事前評価とそれに 基づく対策の検討, $1987 / 89$ 年度研究成果報告」人間 環境系研究報告集, GO 28-N11-01，81-96.

大羽 裕 (1990): 酸性下降物が土壤の化学性に及ぼす 影響と本邦土壤の酸中和能の評価.「酸性雨が流域生 態系におよぼす影響の事前評価とそれに基づく対策の 検討, $1987 / 89$ 年度研究成果報告」人間環境系研究報 告集. GO 28-N11-01，113-131.

太田正道 (1968): 地向斜型生物礁複合体としての秋吉 石灰岩層群. 秋吉台科学博物館報告, 5, 1-44.

Ota, M. (1977): Geological studies of Akiyoshi, Pt. 1, General geology of Akiyoshi limestone group. Bull. Akiyoshi-dai Mus. Nat. Hist., 12, $1-33$.

太田陽子 (1990): 南・北大東島の離水サンゴ礁からみ た第四紀地殼変動の特性. 昭和 62,63 , 平成元年科学 研究補助金 (総合研究 A) 研究成果報告, $102 \mathrm{p}$.

小澤智生・平 朝彦・小林文夫 (1985): 西南日本の帯 状地質構造はどのようにしてできたか. 科学，55，413.

Sano, H. and Kanmera, K. (1991): Collapse of ancient oceanic reef complex-What happened during collision of Akiyoshi reef complex? Sequence of collisional collapse and generation of collapse products. J. Geol. Soc. Japan, 97, 631-644.

石灰石鉱業協会 (1983): 日本の石灰石。石灰石鉱業協 会, $503 \mathrm{p}$.

平 朝彦 (1990): 日本列島の誕生. 岩波新書, $226 \mathrm{p}$.

滝根町史編さん委員会（1990）：滝根町史第一巻自然編。 滝根町, $361 \mathrm{p}$.

Thornthwaite, C.W. (1948): An approach toward a rational classification of climate. Geogr. Rev., 38, 55-94.

Trudgill, S.T. (1975): Measurements of erosional weight-loss of rock tablets. British Geographical Research Group. Techn. Bull., Norwich, 17, 13-19.

Trudgill, S.T. (1976): The erosion of limestones under soil and the long term stability of soil vegetation systems on limestone. Earth Surface Processes, 1, 31-41.

漆原和子 (1991): 日本における石灰岩片の溶食率の地 域差. 地域学研究, 4, 107-117.

漆原和子編（1996)：カルスト一その環境と人びととの かかわり一. 大明堂, $325 \mathrm{p}$.

漆原和子・Miotke, F.-D. (1998): 福島県あぶくま洞 付近の大理石地域と非石灰岩地域における土壤中の二 酸化炭素濃度. 駒澤地理, 34, 35-46.

漆原和子 - 喜納宏之 - 新垣和夫 - 佐々木正和 - Miotke, F.-D.（1997)：南大東島における石灰岩片の溶食率 と土畩中の $\mathrm{CO}_{2}$ 濃度. 駒澤地理, $33,33-47$.

漆原和子・鹿島愛彦・榎本浩之 ·庫本 正 ·仲程 正 · フランツ・ディーターミオトケ (1998): 日本におけ る石灰岩片の溶食率と土壤中の二酸化炭素の経年変化. $\mathrm{IGCP}$ 特別シンポジウムアジア・太平洋地域の形成 と地球環境, 日本 IGCP 国内委員会（日本学術会議 国際学術協力事業研連専門委員会), 33-36.

Urushibara-Yoshino, K., Miotke, F.-D. and Research Group of Solution rates in Japan (1998): The solution rate of limestone tablets and $\mathrm{CO}_{2}$ measurements in limestone areas of Japan. Supplementi di Geografia Fisica e Dinamica Quaternaria, Suppl. III, T. 4, 35-39.

吉野和子（漆原和子）（1998）：日本におけるカルスト化 過程の体系化. 平成 7 -9 年度文部省科学研究費補助 金〔基盤研究 (c)（2)〕研究成果報告書，145 p.

吉村和久 (1985): 石灰岩の溶解と温度. 山口ケイビン グクラブ会報，21，3-5.

吉村和久 - 中村 久 (1991): 秋吉台の酸性雨。秋吉台 科学博物館報告, $26,9-20$.

Yuan, D. (1991): Karst of China. Geological Publishing House, Beijing, China, $224 \mathrm{p}$.

Yuan, D. (1997): Sensitivity of karst process to environmental change along the PEPII transect. Quaternary International, 37, 105-113.

(1998 年 9 月 21 日受付, 1998 年 12 月 14 日受理) 